\title{
Risk factors that may occur in the process of closing and greening the Lupeni Mining Exploitation
}

\author{
Manuel Cristian Savulescu ${ }^{1 *}$, Andreea Cristina Tataru ${ }^{1}$, Aurora Stanci $^{2}$, and Dorin Tataru ${ }^{11}$ \\ ${ }^{1}$ University of Petrosani, Department of Mechanical and Industrial Engineering and Transports, \\ Universittii street, No.20, Petrosani, Romania \\ ${ }^{2}$ University of Petrosani, Departament of Management, Environmental Engineering and Geology, \\ Universittii street, No.20, Petrosani, Romania
}

\begin{abstract}
The process of closing and greening the Lupeni Mining Exploitation is a very complex one. The closure of the mining operation is done in stages for the underground and the surface based on a closure project. When implementing the closure and greening project, all occupational safety and health regulations must be observed. As part of the process of closing and greening a mining operation, it is necessary to redo the risk factor assessment sheets with additional measures for the closure and greening of the mining operation. In this paper we aim to establish what are the main risk factors that can be encountered in the process of closure and greening of the Lupeni Mining operation.
\end{abstract}

\section{Introduction}

The starting point in optimizing the activity of prevention of work accidents and occupational diseases at work is the risk assessment.

Whether it is a job, a workshop or an enterprise, such an analysis allows the ranking of risks according to their size and the efficient allocation of resources for priority measures.

Risk assessment involves identifying all risk factors in the analyzed system and quantifying their size based on the combination of two parameters: severity and frequency of the maximum possible consequence on the human body. Thus, partial risk levels are obtained for each risk factor, respectively global risk levels for the entire analyzed system.

Law no. 319/2006 on safety and health at work contains the following provisions regarding the mandatory risk assessment:

- the employer has the obligation "to assess the risks to the safety and health of workers, including the choice of work equipment, substances or chemical preparations used and the arrangement of workplaces" (art. 7, paragraph 4, letter a);

- the employer has the obligation "to carry out and be in possession of a risk assessment for occupational safety and health, including for those groups sensitive to specific risks" (art. 12 , paragraph 1 , letter a).

\footnotetext{
*Corresponding author: savio_scm@yahoo.com
} 
Also, through the provisions of art. 13, lit. b, Law no. Regulation (EC) No 319/2006 on occupational safety and health states that, in order to ensure occupational safety and health and to prevent accidents at work and occupational diseases, employers are required to 'draw up a prevention and protection plan consisting of technical measures, health, organizational and other nature, based on risk assessment, to be applied according to the unit-specific working conditions ".

In accordance with Art. 15, para. 1, of H.G. no. 1425/2006 for the approval of the Methodological Norms for the application of the provisions of the Law on safety and health at work no. 319/2006, the first of the prevention and protection activities carried out within the enterprise and / or unit is represented by "hazard identification and risk assessment for each component of the respective work system executing, workload, means of work / work equipment and work environment / jobs ".

To facilitate the fulfillment of employers' legal obligations in the field of occupational injury and disease risk assessment, a relatively large number of methods have been designed and are currently used. [1]. [2]. [3]

\section{Lupeni Mining Exploitation}

In the basement of the Jiu Valley Carboniferous Basin is concentrated the largest coal deposit in Romania. It is located in the extreme southern part of Hunedoara county, in the Petrosani intramountain depression, on a length of about $42 \mathrm{~km}$ and with a width varying between 3 and $7 \mathrm{~km}$ and began to be known since 1782, when layers of coal were observed, which ignited and burned for a long time.

The coal mining activity in the Jiu Valley is managed by Complexul Energetic Hunedoara S.A.

The object of activity is the production, supply and sale of electricity based on coal, production, dispatching, transport, distribution and supply of thermal energy, conducting geological research for the discovery of coal reserves, exploitation of coal deposits, maintenance, etc. in order to operate integrated and to become a main actor in the regional plan by capitalizing with maximum efficiency the potential that Romania has in the field.

The branches of the Company that carry out mining activities are the following:

- Lonea Mining Branch

- Livezeni Mining Branch

- Vulcan Mining Branch

- Lupeni Mining Branch

- Prestserv Petrosani Branch

The Lupeni Mining Branch is located in the western part of the Jiu Valley, on the administrative territory of Lupeni Municipality. Lupeni mining is one of the most important mining operations in the Jiu Valley.
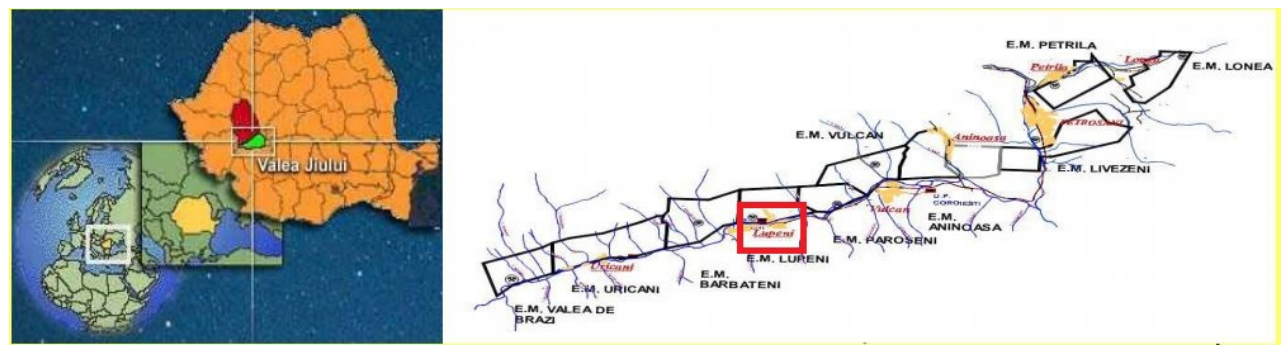

Fig. 1. Map of Mining in the Jiu Valley 
Lupeni Mining will have to start the process of closing and greening the mining both for the underground and for the surface. The closure and greening process will be done in stages based on a closure and greening project

\section{Risk factors that may occur in the process of closure and greening of the Lupeni Mining Exploitation}

Risk can be defined as a potential event that, if it occurs, causes loss, damage, destruction, suffering, etc. Depending on the field in which the events may occur or their nature, we can speak of a great diversity of risks.

The risks are present in all economic and industrial activities that are manifested both by economic losses, failures in installations, equipment and by the occurrence of minor or major accidents with particularly serious consequences resulting in deaths and injuries, environmental pollution.

The assessment of risk levels stimulates the interest of economic operators to improve their working and environmental conditions, respectively to take measures to move from high risk levels to lower, acceptable levels. [1]. [2]. [3]

\subsection{Risk assessment methods and tools}

There are many risk assessment methods and tools to help businesses and organizations assess their risks to staff safety and health.

They can be classified into two broad categories: qualitative methods based on risk checklists and more complex quantitative methods that allow the level of risk to be determined in the workplace based on the combination of severity and frequency of consequence. predictable maximums of the action of the risk factor on the human body.

The choice of assessment method depends on: the type of activity and equipment used, the number of workers involved, working conditions, particular characteristics of the workplace and specific risks. [1]. [2]. [3]

\subsection{Stages of risk assessment}

Regardless of the method used, the quantitative risk assessment involves the following 5 steps:

A. Identification of risk factors (hazards)

- delimitation of the workstation

- setting up the evaluation team

- field analysis and identification of risk factors (working tool: Lists of risk factors)

B. Risk assessment

- establishing the maximum foreseeable consequence on the human body

(working tool: Lists with the maximum possible consequences)

- establishing the gravity class (working tool: grids with gravity classes)

- setting the frequency class (working tool: grids with frequency classes)

- setting partial risk levels (scale of risk levels)

- calculation of the global risk level per workplace

C. Hierarchy of risks and establishment of prevention and protection measures (form: Proposed measures sheet)

D. Implementation of measures (decisions taken in the Occupational Safety and Health Committee for the elaboration of the prevention and protection plan) 
E. Monitoring the application of measures and re-evaluation (internal control)

The results of the risk assessment are recorded in two summary documents:

- risk assessment form;

- sheet of proposed measures.

The results of the risk assessment at the workplaces are the basis for the elaboration of the prevention and protection plans, as well as for the realization of the own instructions for safety and health at work.

Currently in the field of mining, the closure and greening of mining operations presents sources of risk and production of natural and technological disasters. These sources of risk and the occurrence of natural and technological disasters are much more carefully studied today by scientists and specialists.

Depending on the mode of production and the consequences of the events generated, the risks are classified into:

- natural risks;

- technological risks;

- biological risks;

- fire risk.

The risk of fire is a risk that occurs with a much higher frequency and with more or less major consequences compared to other risks in the case of underground operations.

A relatively large number of methods have been designed and are currently used to facilitate the fulfillment of employers' legal obligations in the field of risk assessment.

From the multitude of methods used worldwide and nationally for risk assessment, in this paper we chose to use the method developed by I.N.C.D.P.M. Bucharest.

This method was approved by the Ministry of Labor and Social Protection in 1993, revised in 1996, edited in 1998 and republished in 2002. [1]. [2]. [3], [4]

The study was carried out based on the data provided by Mina Lupeni through job descriptions, lists of technical equipment, technical books of equipment used, regulations for granting personal protective equipment, closure and greening of the Lupeni Mine, information on technological processes and the development of the work process for each job, received from the management and technical staff of the company, as well as the own observations made during the documentation visits and follow-up of the activity for each job.

In the process of closure and greening there are several risk factors that must be taken into account when determining the overall level of risk in the workplace. These risk factors are determined by phenomena that occur only in the process of closure and greening of mining operations. These risk factors may also be present in the case of the process of closing and greening the Lupeni Mining Exploitation.

These risk factors are related to the work environment and fall into the category of chemical risk factors and are:

- smoke, toxic gases that may occur above the permitted limits $(\mathrm{CO}, \mathrm{CO} 2, \mathrm{SO} 2, \mathrm{CH} 4$, $\mathrm{NO} 2)$

- sudden drop in atmospheric pressure, causing disturbances to general ventilation, resulting in methane accumulations

- floods, borscht eruptions, roof hits, gas bags under pressure

Within the process of closing and greening the Lupeni Mining Exploitation, there are also certain high and specific risk areas. These areas and risk factors specific to each area are presented in Table 1.

Table 1 presents risk factors that can generate accidents or pre-occupational diseases with serious, irreversible consequences, respectively death or disability for jobs specific to the process of underground closure of a mining operation, namely abatement, coal preparation works, mining works. tailings preparation, mining maintenance, transport flow, pump station and belt transport flow. 
Table 1. High and specific risk areas for Lupeni Mining and their specific risk factors

\begin{tabular}{|c|c|c|}
\hline $\begin{array}{c}\text { Nr. } \\
\text { of } \\
\text { crt. }\end{array}$ & $\begin{array}{c}\text { Area } \\
\text { (Working place) }\end{array}$ & Risk factors \\
\hline \multirow[t]{5}{*}{1} & \multirow[t]{5}{*}{ Adit end } & F1 What may cause explosions caused by coal dust or explosive gases \\
\hline & & $\begin{array}{l}\text { F2 What can cause fires or mine fires caused by flammable gases or } \\
\text { vapors }\end{array}$ \\
\hline & & $\begin{array}{l}\text { F3 Mechanical or thermal risk of collapse or collapse and fluid flow at } \\
\text { tem peratures }\end{array}$ \\
\hline & & F4 Physical risk of noise and vibration and pneumoconiogenic dust \\
\hline & & F5 Natural risk factors represented by water floods \\
\hline \multirow[t]{5}{*}{2} & \multirow[t]{5}{*}{$\begin{array}{l}\text { Coal preparation } \\
\text { work }\end{array}$} & $\begin{array}{l}\text { F6 What may cause explosions caused by coal dust, explosive gases } \\
\text { or explosive substances }\end{array}$ \\
\hline & & $\begin{array}{l}\text { F7 Chemical risk factors that may be caused by gases and textiles or } \\
\text { explosives }\end{array}$ \\
\hline & & $\begin{array}{l}\text { F8 Mechanical and thermal risk from collapses, collapses or fluid jets } \\
\text { at high temperatures and pressures }\end{array}$ \\
\hline & & F9 Physical risk of noise and vibration or pneumoconiogenic dust \\
\hline & & F10 Natural risk factors represented by water floods \\
\hline \multirow[t]{5}{*}{3} & \multirow[t]{5}{*}{$\begin{array}{c}\text { Waste } \\
\text { preparation work }\end{array}$} & $\begin{array}{l}\text { F11 What may cause explosions caused by coal dust, explosive gases } \\
\text { or explosive substances }\end{array}$ \\
\hline & & $\begin{array}{l}\text { F12 Chemical risk factors that may be caused by gases and textiles or } \\
\text { explosives }\end{array}$ \\
\hline & & $\begin{array}{l}\text { F13 Mechanical and thermal risk from collapses, collapses or fluid jets } \\
\text { at high temperatures and pressures }\end{array}$ \\
\hline & & F14 Physical risk of noise and vibration or pneumoconiogenic dust \\
\hline & & F15 Natural risk factors represented by water floods \\
\hline \multirow[t]{5}{*}{4} & \multirow[t]{5}{*}{$\begin{array}{c}\text { Mining } \\
\text { maintenance }\end{array}$} & $\begin{array}{l}\text { F16 What may cause explosions caused by coal dust, explosive gases } \\
\text { or explosive substances }\end{array}$ \\
\hline & & $\begin{array}{l}\text { F17 Chemical risk factors that may be caused by gases and textiles or } \\
\text { explosives }\end{array}$ \\
\hline & & $\begin{array}{l}\text { F18 Mechanical and thermal risk from collapses, collapses or fluid jets } \\
\text { at high temperatures and pressures }\end{array}$ \\
\hline & & F19 Physical risk of noise and vibration or pneumoconiogenic dust \\
\hline & & F20 Natural risk factors represented by water floods \\
\hline \multirow[t]{5}{*}{5} & \multirow[t]{5}{*}{ Transport flow } & F21 What may cause explosions caused by coal dust or explosive gases \\
\hline & & F22 Chemical risk factors that may be caused by gases and textiles \\
\hline & & $\begin{array}{l}\text { F23 Mechanical and thermal risk from collapses, collapses or fluid jets } \\
\text { at high temperatures and pressures }\end{array}$ \\
\hline & & F24 Physical risk of noise and vibration or pneumoconiogenic dust \\
\hline & & F25 Natural risk factors represented by water floods \\
\hline \multirow[t]{5}{*}{6} & \multirow[t]{5}{*}{ Pump station } & F26 What can cause explosions caused by coal dust or explosive gases \\
\hline & & F27 Chemical risk factors that may be caused by gases and textiles \\
\hline & & $\begin{array}{l}\text { F28 Mechanical and thermal risk from collapses, collapses or fluid jets } \\
\text { at high temperatures and pressures }\end{array}$ \\
\hline & & F29 Physical risk of noise and vibration or pneumoconiogenic dust \\
\hline & & F30 Natural risk factors for floods \\
\hline \multirow[t]{5}{*}{7} & \multirow[t]{5}{*}{$\begin{array}{l}\text { Conveyor flow } \\
\text { with belts }\end{array}$} & $\begin{array}{l}\text { F31 What can be caused by explosions caused by coal dust or } \\
\text { explosive gases }\end{array}$ \\
\hline & & F32 Chemical risk factors that may be caused by gases and textiles \\
\hline & & $\begin{array}{l}\text { F33 Mechanical and thermal hazard from collapses, collapses or fluid } \\
\text { jets at high temperatures }\end{array}$ \\
\hline & & F34 Physical risk of noise and vibration or pneumoconiogenic dust \\
\hline & & F35 Natural risk factors represented by floods \\
\hline
\end{tabular}


In order to reduce the level of risk, it is necessary to apply technical and organizational measures for each risk factor. These measures need to be implemented on an ongoing basis.

For risk factors that can cause explosions of coal dust and explosive gases as technical and organizational measures we have:

- Removal of coal dust deposits

- Sprinkle the deposited dust with water

- Wetting by injecting pressurized water into the layer

- Stabilization of basic galleries, head and transport flows

- Installation of inert dust dams

- Use of air-water sprayers in the operation of evacuating coal from the basic sliced front and in the transhipment points of transport flows

- Maintaining the main ventilation system in working order at all times

- Ensure that air flow rates set by the expansion projects.

- Ensuring the air flow according to the ventilation project

- Permanent methane measurement

- Evacuation of workers from the area when the methane concentration reaches $2 \%$ in mining works

- Eng CFL, foremen, and CAMS will contact every 2 hours with the operator of the power plant in order to inform on the methane concentration

- maintaining the initial profiles of the preparatory mining works as well as the abatements

- Strict observance of the provisions of the shooting provisions and the provisions of law no. 126/1995 with the completions and modifications in force.

- Compliance with the applicable OSH regulations

For risk factors that can generate fires or mine fires produced by flammable gases or vapors we have:

- determining the tendency of coal to ignite

- avoiding the remainder of combustible materials in the exploited space

- isolation of areas exploited with dams

- siltation or nitrogen inertization of closed areas

- control of gas concentrations $(\mathrm{CH} 4, \mathrm{C} 0, \mathrm{CO} 2, \mathrm{O} 2)$ from isolated works with dams

- use of trisodium phosphate aerosols

For risk factors that can generate mechanical or thermal risk generated by collapse or collapse and jet of fluids at temperatures we have:

- compliance with approved reinforcement monographs and permits for additional support in areas where the situation requires it

- compliance with the support density according to the reinforcement monograph

- compliance with the framework method, the work permit and the occupational safety and health document

- following the correct direction of the roof and avoiding dangerous openings

- proper support of the niches and the intersection of the abbeys with the basic galleries, respectively the head

- the total collapse of the rocks from the roof of the layer with the complete closure of the gap resulting from exploitation.

For physical risk factors generated by noise and vibration or dust we have:

- performing the periodic overhaul of work equipment and replacement of worn parts and subassemblies;

- use of earphones

- reduction of vibration levels with the help of attenuators

- spraying with industrial water the materials

- use of water drilling for shooting work

- use of artificial fog curtains with air-water sprayers 
- use dust masks

- normalized wet drilling of mine holes

For natural risk factors represented by water floods we have:

- identification of old works with water accumulations near the abattoirs

- the execution of the works in abattages located near the old works with water accumulations will be done only on the basis of a project approved by the legal person

- on the topographic maps will be written all the details related to the extension and depth of the old underground works, the existence of possible water accumulations

- the abattoirs located in the vicinity of the previously exploited and flooded areas will be put into operation only after the water from the old constructions has been evacuated

- special training of workers on the occurrence of such events

- establishing the drainage system from the mine coming from infiltrations or water floods from old works, aquifers (borscht);

- establishing the system for the prevention of water eruptions and for the protection of works, installations and mining works from the effect of these eruptions

- fixing the safety pillars for old flooded areas and for surface waters

- elaboration of projects for the mining works that are executed in strata or rocks with dangers of water eruption

- construction of basins for collecting groundwater and establishing their cleaning period

- the corresponding dimensioning of the channels on the galleries according to the water flow

For chemical risk factors that can be caused by gases and textiles or explosives we have:

- Observance of the required air flow at the parametrically designed

- Observance of the maximum distance allowed between the last ventilation column tube and the working front

- Observe the ventilation time after shooting

- Permanent monitoring of methane concentrations and permanent measurement of methane concentration

- Strict observance of the provisions of the shooting provisions and the provisions of law no. 126/1995 with the completions and modifications in force.

- Compliance with the applicable OSH regulations

For risk factors that can generate explosions produced by coal dust or explosive gases we have:

- Removal of coal dust deposits

- Sprinkle the deposited dust with water

- Wetting by injecting pressurized water into the layer

- Stabilization of basic galleries, head and transport flows

- Installation of inert dust dams

- Use of air-water sprayers in the operation of evacuating coal from the basic sliced front and in the transhipment points of transport flows

- Maintaining the main ventilation system in working order at all times

- Ensuring the air flows established by the aeration projects.

- Ensuring the air flow according to the ventilation project

- Permanent methane measurement

- Evacuation of workers from the area when the methane concentration reaches $2 \%$ in mining works

- Eng CFL, foremen, and CAMS will contact every 2 hours with the operator of the power plant in order to inform on the methane concentration

- Maintaining the initial preparatory mining works as well as the abatements

For chemical risk factors that can be caused by gases and textiles we have: 
- Observance of the required air flow at the parametrically designed

- Permanent monitoring of methane concentrations and permanent measurement of methane concentration

\section{Conclusions}

Within the process of closing and greening the Lupeni mining operation, there are high and specific risk areas

Areas with a high and specific risk may cause accidents or pre-occupational diseases with serious, irreversible consequences, respectively death or disability for workplaces

Risk factor in high-risk areas and specifically are risk factors which can lead to explosions of coal dust or gas blasting the technical and organizational measures, risk factors that can cause fires or fires of mine product gas or vapor, risk factors that may generate mechanical or thermal risk generated by collapse or collapse and jet of fluids at temperatures, physical risk factors generated by noise and vibration or dust, natural risk factors represented by water floods.

Technical and organizational measures are needed to reduce the level of risk.

Technical and organizational measures are established for each risk in part by work.

These measures need to be implemented on an ongoing basis

\section{REFERENCES}

1. 1. A Ozunu., C. Anghel, Technological risk assessment and environmental security, Publishing House Accent, Cluj-Napoca, (2007);

2. G. B. Babut, R. I. Moraru, Occupational Risk Assessment: Imperatives for Process Improvement.Quality - Access to Success, Vol. 19 Issue 166, p133-144. 12p, (2018)

3. G. B. Babut; R. I. Moraru P. S. Mihai; D. N. Fraitag, Understanding and managing worker's exposure to specific risks, MATEC Web of Conferences; Vol. 305, (2020).

4. F. J. G.-Gómez, C. González-Gaya, V. F.. Rosales-Prieto, An Approach to Health and Safety Assessment in Industrial Parks, Sustainability 2020, 12(9) (2020) 